\title{
Benthic microalgal communities in the inner part of the Bahía Blanca estuary (Argentina): a preliminary qualitative study
}

\section{Communautés microalgales benthiques dans la partie intérieure de l'estuaire de la Bahía Blanca (Argentine) : étude qualitative préliminaire}

\author{
Elisa R. Parodi *, Sonia Barría de Cao \\ Laboratory of Aquatic Ecology, Department of Biology, Biochemistry and Pharmacy, Universidad Nacional del Sur and Instituto Argentino de \\ Oceanografía (IADO), Camino de la Carrindanga km 71/2, 8000 Bahía Blanca, Argentina
}

\begin{abstract}
The intertidal zone of the inner part of the Bahía Blanca estuary, Argentina is characterised by the presence of muddy tidal flats and salt marshes, habitats for burrowing crabs and halophytic plants. The surface layer of the sediments is composed of silt and clay. The sediments are substrate for the proliferation of benthic microalgal communities. The aim of this study was to analyse qualitatively the species composition of these communities and their role in the stabilisation of the sediments. Samples came from two stations: Puerto Cuatreros and Villarino Viejo. Puerto Cuatreros is an old pier without harbour activities closer than Villarino Viejo to the harbour zone affected by dredging. Both stations showed similar physical and chemical parameters. In addition, the benthic microalgal communities at both stations were comprised of cyanophytes and diatoms. The main difference between the two stations was the relative frequency of the algae — cyanophytes were predominant in Villarino Viejo while diatoms predominated in Puerto Cuatreros. Presumably, the difference was due to the major disturbance of the first due to deposition of particles of the fluid mud layer produced by the nearby dredging. Major species of cyanophytes were Microcoleus chtonoplastes and Oscillatoria limosa. Diatom assemblages were very diverse since the estuarine characteristics of the system allow the coexistence of marine, freshwater and estuarine species; also some of these species may be present in the plankton community.
\end{abstract}

(C) 2002 Ifremer/CNRS/IRD/Éditions scientifiques et médicales Elsevier SAS. All rights reserved.

\section{Résumé}

La zone intertidale de l'estuaire de la Bahia Blanca est caractérisée par des fonds vaseux soumis aux marées et des marais salants, qui constituent des habitats pour les crabes fouisseurs et les plantes halophytes. La surface des sédiments, vaseuse et argileuse, constitue un bon substrat pour la prolifération des communautés benthiques microalgales. Cette étude analyse la composition spécifique de ces communautés et leur rôle dans la stabilisation des sédiments. Les échantillons proviennent de deux stations : Puerto Cuatreros et Villarino Viejo. La première est un ancien embarcadère sans activité portuaire, proche cependant de la zone portuaire que Villarino Viejo affectée par les dragages. Les deux stations présentent des caractéristiques physiques et chimiques similaires et les communautés benthiques de microalgues sont composées de cyanophycées et de diatomées. La différence principale entre ces deux stations tient à la fréquence relative des algues ; les cyanophycées dominent à Villarino Viejo et les diatomées à Puerto Cuatreros. Cette différence serait due à l'environnement plus perturbé de la première station liée à la proximité de la zone de dragage. Les principales espèces de cyanophytes sont Microcoleus chtonoplastes et Oscillatoria limosa. Les communautés de diatomées sont beaucoup plus diversifiées, l'écosystème estuarien permettant la coexistence d'espèces marines, estuariennes et d'eau douce. Quelques-unes de ces espèces apparaissent également dans le plancton.

(C) 2002 Ifremer/CNRS/IRD/Éditions scientifiques et médicales Elsevier SAS. Tous droits réservés.

Keywords: Benthic microalgal communities; Microbial mats; Sediments stabilisation

Mots clés: Microphytobenthos; Stabilisation des sédiments

\footnotetext{
* Corresponding author.

E-mail address: eparodi@criba.edu.ar (E.R. Parodi).
} 


\section{Introduction}

Many studies about different planktonic and macrobenthic communities in the Bahía Blanca estuary have been carried out since the 1980s (Perillo et al., 2000 and the papers cited therein), to examine the biodiversity, structure and dynamics of this estuarine ecosystem. These works established the basis for later studies to assess the environmental impact produced by the settlement of a thermoelectric plant, different petrochemical industries and principally by the major dredging effort of the principal channel and harbour areas (Perillo et al., 2000, 2001). Dredging is one of the most important human impacts on the succession and conservation of benthic communities in this area of intense harbour activity, causing considerable substrate alterations and thus, alterations in the conformation and dynamics of the biological communities, not only confined to the work areas but also affecting areas into which sediments are displaced. In the inner part of the Bahía Blanca estuary, the sediments consist of a mixture of silt and clay predominately. Nevertheless, until now no studies concerning the benthic microalgae communities associated with the sediments have been carried out in this area.

Microbial mats probably are among the oldest structural ecosystems on earth (van Gemerden, 1993); they are predominantly populated by prokaryotes (heterotrophic plus phototrophic bacteria and blue-green algae) and epipelic diatoms that colonise surfaces of unconsolidated sediments of mudflats and tidal marshes (Paterson, 1990). These microbial mats exhibit different morphologies, since the interrelations between the physical and chemical factors and the organisms favour the prevalence of different species. Further on, these communities are characterised by chemical gradients, by the relative abundance of phototrophic microorganisms, and by the different stratification of the microbial population into distinct layers (Stolz, 2000).

Microbenthic communities are often conspicuously lining surface sediments of aquatic environments (Dawes, 1998; Graham and Wilcox, 2000) providing energy for mat growth and gelling activities (Paerl and Pinckney, 1996). The role of blue-green algae in stabilising loose sediments has been recognised in studies of microbial mats (Golubic et al., 2000). The gliding motility of their filaments in conjunction with a copious excretion of a polysaccharide sheath enables these organisms to spread rapidly over newly deposited sediments. But particularly diatoms play an important role in the sediment dynamics of mudflats and intertidal marshes, due to their mucilage secretion which increases consolidation of the particles and reduces erosion (Paterson, 1995). For calculating relative abundance of diatoms in a mat, Wilson and Holmes (1981) recognised for the first time the necessity of taking into consideration only live individuals. Empty frustules in some cases represent about $40 \%$ of total diatoms counted, leading to erroneous conclusions about the relations between the sample assemblage and other ecological variables measured at the site.

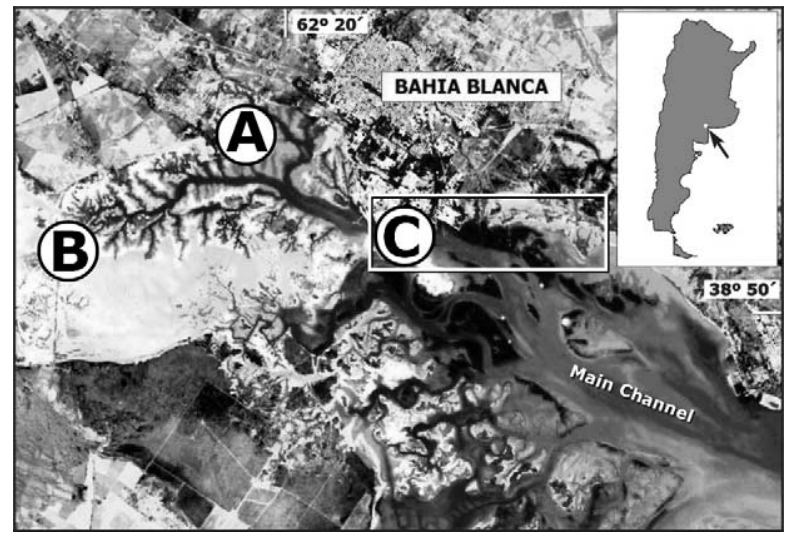

Fig. 1. Satellite map of the Bahía Blanca estuary showing the locations of the sampling stations Puerto Cuatreros (A) and Villarino Viejo (B) and the nearby dredging areas $(\mathrm{C})$.

Therefore, the goal of the present preliminary study was to analyse qualitatively the mats' microalgal species composition, and the structure and assemblage of the communities, especially diatoms, with scanning electron microscopy, since with these techniques it is possible to determine accurately their vitality in the sample, thus allowing more precise interpretations of their ecological role in the future, i.e. their role in the stabilisation of the sediments disturbed by the dredging. In Argentina, there are no precedents for this ecological type of work, although some pioneering studies on the floristic composition of Cyanophyta in intertidal marshes have been done more than 30 years ago (Olivier et al., 1966; Halperin, 1967, 1969, 1970).

\section{Materials and methods}

\subsection{Study area}

This study was carried out at the coastal region of the inner part of the Bahía Blanca estuary, Argentina (Fig. 1), where the principal channel has a width of the order of $400 \mathrm{~m}$ at the dredging areas (Fig. 1C), diminishing progressively headward where it reaches values of the order of $50 \mathrm{~m}$. Maximum depth varies from $12 \mathrm{~m}$ at dredging areas to less than $1 \mathrm{~m}$ at the head (Gómez et al., 1996). This area is characterised by silt and clay muddy tidal flats and salt marshes, habitats of burrowing crabs (Chasmagnatus granulata) and halophytic plants (Salicornia ambigua). In the intertidal zone microalgal mats are tidally inundated and exposed.

Puerto Cuatreros station (Fig. 1A) is an old pier without harbour activities, closer than Villarino Viejo (Fig. 1B) to the harbour zone, where approximately $500000 \mathrm{~m}^{3}$ of silt and clay are removed annually by dredging causing an important layer of fluid mud that remains in suspension for a month (Fig. 1C). Hence, Puerto Cuatreros is more influenced by the suspended sediments and, in general, by the impact of dredging (Perillo et al., 2001). 
Table 1

Physical and chemical parameters in both stations

\begin{tabular}{llllll}
\hline Stations & $C_{\text {total }}(\%)$ & $N_{\text {total }}(\%)$ & $P_{\text {extractable }}(\mathrm{ppm})$ & $\mathrm{pH}$ & Salinity \\
\hline Puerto Cuatreros & 2.98 & 0.21 & 8.82 & 8.6 & 35.6 \\
Villarino Viejo & 2.44 & 0.19 & 8.71 & 8.5 & 9.2 \\
\hline
\end{tabular}

\subsection{Methods}

Sampling was done in autumn 2001. Samples came from two stations: Puerto Cuatreros (Fig. 1A) and Villarino Viejo (Fig. 1B). At each station, three samples (a, b and c) were obtained under low tidal conditions between the low tide level and the low limit of the population of Salicornia ambigua. Samples "a" were taken with a manual Plexiglas corer ( $3 \mathrm{~mm}$ thick, total sediment volume $\left.1 \mathrm{~cm}^{3}\right)$ and used for identification of the taxa under light microscopy. Samples "b" were collected from the sediment surface and then processed for scanning electron microscopy (SEM). Samples "c" were taken with a Plexiglas manual corer $(3 \mathrm{~cm}$ thick, total sediment volume $30 \mathrm{~cm}^{3}$ ) for analysis of physical and chemical parameters.

For SEM, samples were fixed in a mixture of $2.5 \%$ glutaraldehyde in cacodilate buffer $0.05 \mathrm{M}$; then they were washed in the same buffer, dehydrated in a acetone series
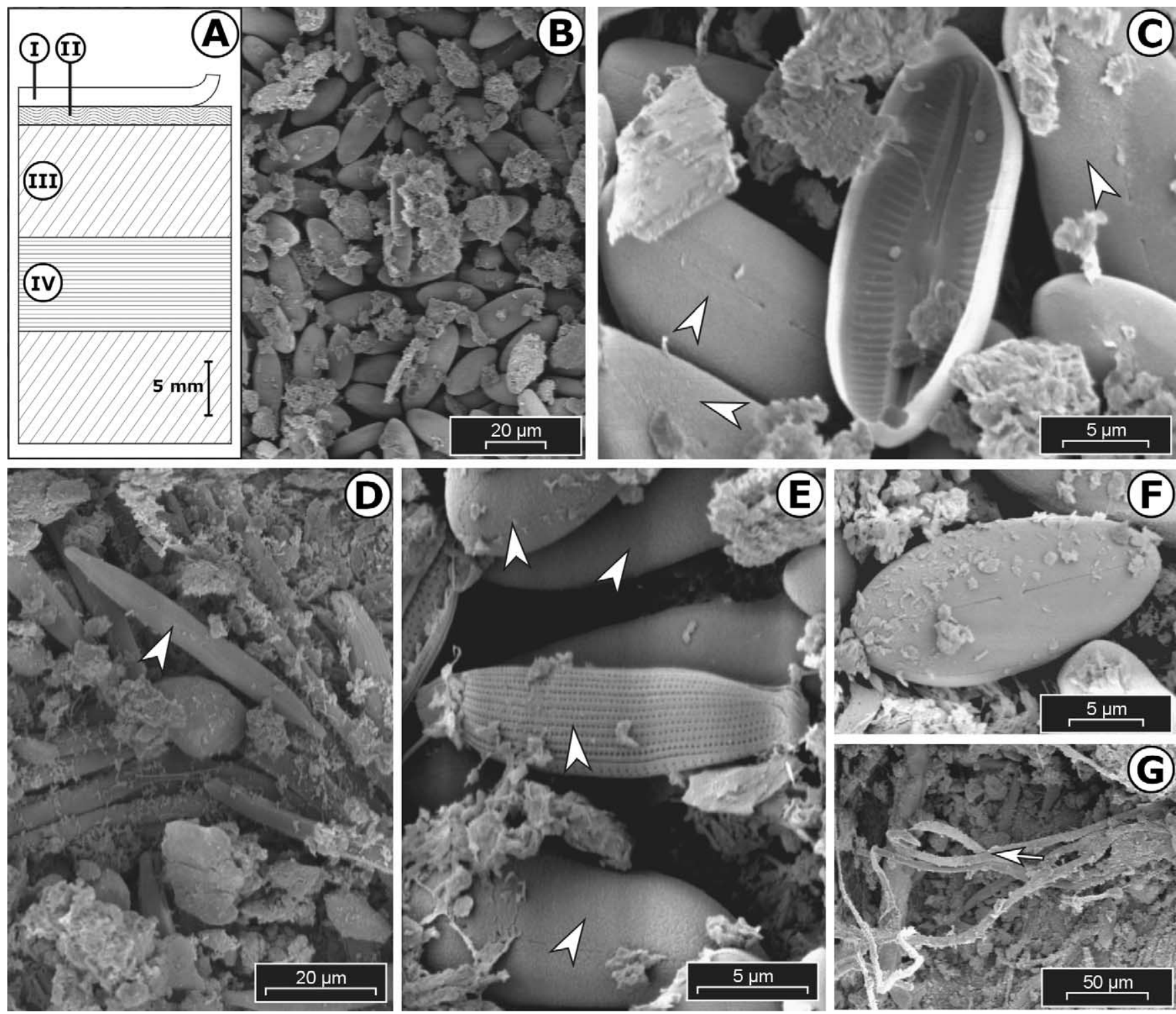

Fig. 2. Benthic microalgal communities in Puerto Cuatreros. (A) Scheme of a vertical section, I: superficial layer inhabited by diatoms; II: sub-superficial layer with predominance of cyanophyte; III: sedimentary substrate with silk and clay; IV: anoxic layer. (B) Layer I, general view of the surface. (C) Detail of an empty diatom frustule. (D-F) Different views of layer I with another species of diatoms with abundant mucilage and sediment particles to see that alive diatoms predominate (arrowheads). (G) Layer II: superficial view to see the disposition of the filaments of cyanophyte (arrow) immerse in mucilage sheath. 

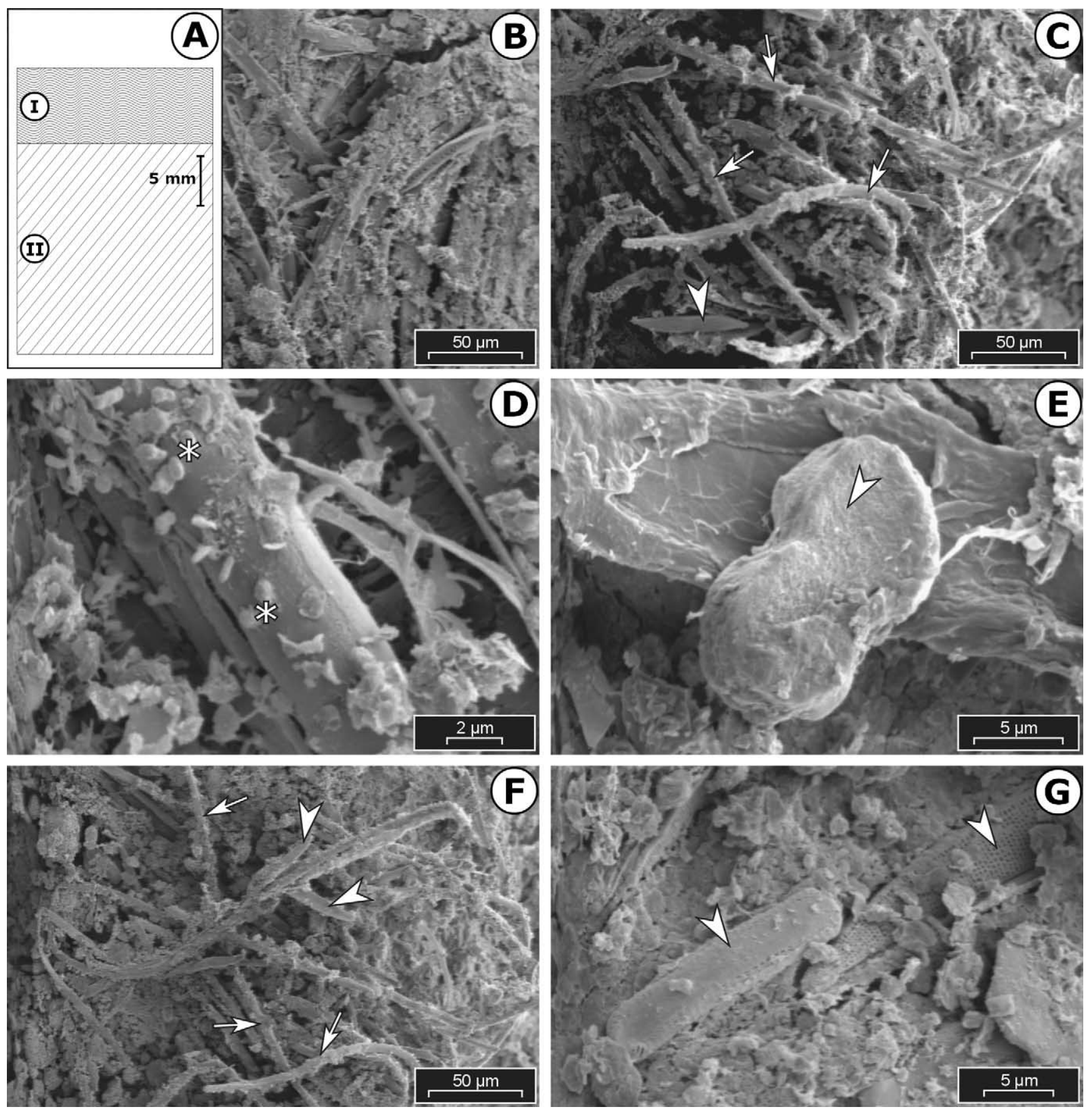

Fig. 3. Benthic microalgal communities in Villarino Viejo. (A) Scheme of a vertical section, I: Superficial layer inhabited by cyanophyte. II: Sedimentary substrata with silk and clay. (B), (C) and (F) Layer I, general view of the surface with predominance of cyanophyte filaments (arrows). Note that the sediment particles are adhered on the sheaths. (D) Unidentified bacteria are on the diatoms $(*)$. (E) and (G) Different views of layer I with diatoms associated to the cyanophyte between the sediments particles.

(10 to $80 \%$ ), and eventually dried by critical point and coated with gold.

Temperature, salinity and $\mathrm{pH}$ were analysed in the field using a Water Quality Checker U-10 Horiba.

$C_{\text {total }}, N_{\text {total }}, P_{\text {extractable }}$ were measured in all the samples in laboratory conditions. Total $N$ was determined by the Kjeldahl method and was measured after Bremner and Mulvaney (1982) and phosphorus by the espectrometric ICP procedure, after Bray and Kurtz (1945); carbon was mea- sured using an autoanalyser for dried combustion Leco Determinator, model CR12. These determinations were made in the Institute LANAIS N-15 (Conicet) at the Universidad Nacional del Sur.

\section{Results and discussion}

Puerto Cuatreros and Villarino Viejo stations (Fig. 1A, B), exhibited similar values for the physical and chemical 
Table 2

Species composition and relative frequency of the organisms present in the microbial mats

\begin{tabular}{|c|c|c|c|}
\hline & Organisms & Puerto Cuatreros & Villarino Viejo \\
\hline \multirow[t]{6}{*}{ Cyanophyta } & Microcoleus vaginatus & $\mathrm{X}$ & XXX \\
\hline & Microcoleus chtonoplastes & $\mathrm{X}$ & $\mathrm{XXXX}$ \\
\hline & Oscillatoria limosa & $\mathrm{X}$ & $\mathrm{XXXX}$ \\
\hline & Lyngbya aestuarii & $\mathrm{X}$ & $\mathrm{X}$ \\
\hline & Hydrocoleum glutinosum & $\mathrm{X}$ & $\mathrm{XX}$ \\
\hline & Arthrospira miniata & & XXX \\
\hline \multirow[t]{13}{*}{ Diatoms } & Nitzschia sigma & & $\mathrm{XX}$ \\
\hline & Nitzschia sp. & XXX & $\mathrm{X}$ \\
\hline & Gyrosigma attenuatum * & & $\mathrm{X}$ \\
\hline & Entomoneis amphyprora $*$ & & $\mathrm{X}$ \\
\hline & Pleurosigma fasciola & $\mathrm{XX}$ & $\mathrm{X}$ \\
\hline & Navicula spp. * & $\mathrm{XX}$ & $\mathrm{X}$ \\
\hline & Surirella gema & XXX & $\mathrm{X}$ \\
\hline & Cylindrotheca closterium $*$ & & $\mathrm{X}$ \\
\hline & Amphiprora alata* & $\mathrm{XX}$ & $\mathrm{X}$ \\
\hline & Stauroneis sp. & XX & $X$ \\
\hline & Scoliopleura sp. & XXX & $\mathrm{XX}$ \\
\hline & Cocconeis sp. ${ }^{*}$ & XXXX & $\mathrm{XX}$ \\
\hline & Paralia sulcata $*$ & & \\
\hline
\end{tabular}

$\mathrm{X}$, rare; XX, abundant; XXX, very abundant; XXXX, dominant.

* Organisms normally found in plankton samples from the study area (Gayoso 1981, 1988).

parameters (Table 1). Nevertheless, the structure and species assemblages of the superficial sediment layers (0-40 $\mathrm{mm}$ in depth) at both stations showed important differences (Figs. 2 and 3). In Puerto Cuatreros (Fig. 2), the yellow-brownish, uppermost covering layer (I), $2 \mathrm{~mm}$ thick, during low tides dried up and crackled in portions that bent and separated from the contiguous green layer (II), of similar thickness. Under both strata there was a sedimentary layer (III) about $35 \mathrm{~mm}$ thick, interrupted by patches of a black layer (IV), $10 \mathrm{~mm}$ thick, probably anoxic. In Villarino Viejo station (Fig. 3), only one well delineated dark-green superficial layer (I), leathery and $5-10 \mathrm{~mm}$ thick was observed.

The benthic microalgal communities were comprised of blue-green algae and diatoms, and all these groups were differently represented in both stations (Table 2). Also a great number of non-photosynthetic bacteria were present. The yellow-brownish layer in the samples from Puerto Cuatreros was inhabited mainly by pennate diatoms. Diatom assemblages were very diverse since the estuarine characteristics of the system allow the coexistence of marine, freshwater and estuarine species (Fig. 2A, F). In addition, some of the species found in surface sediments may have originated from plankton communities (Table 2). It is known that, together with bacterial action, the diatom colonisation of the substrate played a key role in forming and stabilising sediments during the first steps of the succession, since they produced huge amounts of mucilage which allowed the cohesion of the substrate aggregates (Riding, 1994).

The thick dark-green surficial layer (I) of Villarino Viejo was inhabited mainly by cyanophytes with thick mucilaginous sheaths (e.g., Microcoleus vaginatus, M. chtonoplastes, and Hydrocoleum glutinosum) (Fig. 3B) that were principally responsible for the cohesion of this stratum. The same species of cyanophytes (Table 2) were present in the thin sub-surficial, dark-green layer (II) of Puerto Cuatreros. This similar species composition can be explained assuming that both layers have the same origin, being that of the Puerto Cuatreros recently covered by sedimentation of the fluid mud produced by nearby dredging activities, in whose superficial stratum flourished diatoms, thus impeded to reach the same development than that of Villarino Viejo.

\section{Conclusion}

During the first steps of the process of aggregation of sediments, is very important to distinguish between the empty frustules of dead diatoms that form part of the biogenic sediments and those that are alive, that act in the compactness of them by mucilage secretion. In the present study the application of SEM techniques for the analysis of the benthic microalgal communities was of major importance in distinguishing live diatoms in their natural proportions and positions. Similar studies of benthic microalgal communities in the Bahia Blanca estuary would be helpful in future quantitative evaluations of their activity as traps for contaminants or as bioindicator species in these polluted and disturbed areas. The main difference observed between the communities of Puerto Cuatreros and Villarino Viejo was the dissimilar relative frequency of the algal components of the most superficial layer, i.e. diatoms predominated in Puerto Cuatreros while blue-green algae were predominant in Villarino Viejo. Presumably, the difference was due to the major disturbance of the first due to deposition of particles of the fluid mud layer produced by the nearby dredging. 


\section{Acknowledgements}

Support was provided by grant of the Secretaría de Ciencia y Tecnología of the Universidad Nacional del Sur, PGI CSU-24/B 077. Elisa R. Parodi is a research member of the Consejo Nacional de Investigaciones Científicas y Técnicas (CONICET), Argentina.

\section{References}

Bray, R.H., Kurtz, L.T., 1945. Determination of total, organic and available forms of phosphorous in soils. Soil Sci. 59, 39-45.

Bremner, J.M., Mulvaney, C.S., 1982. Nitrogen Total. In: Page, J. (Ed.), Methods of Soil Analysis. Part 2. Am. Soc. Agron. Agronomy Ser. 9, 595-624.

Dawes, C.J., 1998. Marine Botany. 2nd ed. Willey, New York 479 p.

Gayoso, A.M., 1981. Variación estacional del fitoplancton del estuario de Bahía Blanca. PhD Thesis. Fac. Cs. Nat. y Museo. Univ. Nac. , La Plata. Argentina 155 p.

Gayoso, A.M., 1988. Variación estacional del fitoplancton del estuario de Bahía Blanca. Gayana Bot. 45, 241-247.

Golubic, S., Sreong-Joo, L., Brownw, K.M., 2000. Cyanobacteria: architects of sedimentary structures. In: Riding, R., AwramikS. (Eds.), Microbial Sediments. Springer, Berlin, pp. 57-67.

Graham, L.E., Wilcox, L.W., 2000. Algae. Prentice Hall, New Jersey 640 p.

Gómez, E.A., Ginsberg, S.S., Perillo, G.M.E., 1996. Geomorfología y sedimentología de la zona interior del canal principal del estuario de Bahía Blanca. AAS Revista 3 (2), 55-61.

de Halperin, D.R., 1967. Cianofíceas marinas de Puerto Deseado (Argentina). II. Darwiniana 14 (2-3), 273-354.

de Halperin, D.R., 1969. Algunas Cianofíceas de biodermas continentales y marinas nuevas para la Argentina. Darwiniana 15 (3-4), 363-373. de Halperin, D.R., 1970. Cianofíceas marinas del Chubut (Argentina). I. Golfo San José, Golfo Nuevo y alrededores de Rawson. Physis 30 (80), 33-99.

Olivier, S.R., Paternoster, I.K., Bastida, R., 1966. Estudios biocenóticos en las costas de Chubut (Argentina). I. Zonación biocenológicas de Puerto Pardelas (Golfo Nuevo). Bol. Inst. Biol. Mar., Mar del Plata, Argentina 10, 74.

Paerl, H.W., Pinckney, J.L., 1996. A mini-review of microbial consortia: their roles in aquatic production and biochemical cycling. Microb. Ecol. 31, 225-247.

Paterson, D.M., 1990. The influence of epipelic diatom on the erodibility on an artificial sediment. In: Sinoda, H. (Ed.), Proceedings of the Tenth International Symposium on Living and Fossil Diatoms. Jenosuu, Königstein, Germany, pp. 345-355.

Paterson, D.M., 1995. Biogenic structure of early sediment fabric visualized by low temperature scanning electron microscopy. J. Geol. Soc. London 152, 131-140.

Perillo, G.M.E., Piccolo, M.C., Parodi, E.R., Freije, R.H., 2000. The Bahía Blanca Estuary, Argentina. In: Seeliger, U., Kjerfve, B. (Eds.), Coastal Marines Ecosystems of Latin America. Springer, Berlin, pp. 205-218.

Perillo, G.M.E., Pierini, J., Pérez, D., Gómez, E., 2001. Suspended sediment circulation in semi-enclosed docks, Puerto Galván, Argentina. Terra et Aqua 83, 13-20.

Riding, R., 1994. Stromatolite survival and change: the significance of Shark Bay and Lee Stocking Island subtidal columns. In: Krumbein, W.E., Paterson, D.M., Stal, L.J. (Eds.), Biostabilization of Sediments. University of Oldenburg-Verlag, Odenburg, pp. 183-202.

Stolz, J.F., 2000. Structure of microbial mats and biofilms. In: Riding, R., Awramik, S. (Eds.), Microbial Sediments. Springer, Berlin, pp. 1-8.

van Gemerden, H., 1993. Microbial mats: a joint venture. Mar. Geology $113,3-25$.

Wilson, C.J., Holmes, R.W., 1981. The ecological importance of distinguishing between living and dead diatoms in estuarine sediments. $\mathrm{Br}$. Phycol. J. 16, 345-349. 